Meta

Journal des traducteurs

Translators' Journal

\title{
Translation Teaching in China
}

\section{Mu Lei}

Volume 44, numéro 1, mars 1999

Théorie et pratique de la traduction en Chine

The Theory and Practice of Translation in China

URI : https://id.erudit.org/iderudit/003677ar

DOI : https://doi.org/10.7202/003677ar

Aller au sommaire du numéro

\section{Éditeur(s)}

Les Presses de l'Université de Montréal

\section{ISSN}

0026-0452 (imprimé)

1492-1421 (numérique)

Découvrir la revue

\section{Citer cet article}

Lei, M. (1999). Translation Teaching in China. Meta, 44(1), 198-208.

https://doi.org/10.7202/003677ar

\section{Résumé de l'article}

L'enseignement de la traduction est un procédé qui devrait utiliser largement les théories de la traduction. Elles pourraient être étudiées à fond et ainsi se renouveler continuellement. Cet article traite de la situation actuelle de l'enseignement de la traduction en Chine continentale. On traite des méthodes d'enseignement et de la recherche dans ce domaine, ainsi que de la formation des futurs enseignants. L'auteur conclut que le développement de l'enseignement de la traduction dépend de celui des théories de la traduction. Aussi, la formation des traducteurs dépend de la recherche et du développement des théories de l'enseignement de la traduction qui est une partie importante de la traductologie. Par conséquent, les professeurs de traduction devraient concentrer leur attention à la fois sur la traductologie et sur les théories de l'enseignement de la traduction. 


\title{
Translation Teaching in China
}

\author{
mu I ei \\ Hainan University, \\ Hainan, China
}

\begin{abstract}
RÉSUMÉ
L'enseignement de la traduction est un procédé qui devrait utiliser largement les théories de la traduction. Elles pourraient être étudiées à fond et ainsi se renouveler continuellement. Cet article traite de la situation actuelle de l'enseignement de la traduction en Chine continentale. On traite des méthodes d'enseignement et de la recherche dans ce domaine, ainsi que de la formation des futurs enseignants. L'auteur conclut que le développement de l'enseignement de la traduction dépend de celui des théories de la traduction. Aussi, la formation des traducteurs dépend de la recherche et du développement des théories de l'enseignement de la traduction qui est une partie importante de la traductologie. Par conséquent, les professeurs de traduction devraient concentrer leur attention à la fois sur la traductologie et sur les théories de l'enseignement de la traduction.
\end{abstract}

\begin{abstract}
Translation teaching is a process that translation theories could be applied to widely. Indepth study of how translation is taught can set the course for continuous improvement in translation itself. This paper looks at the present situation of translation teaching in mainland China from the following angles: the history of translation teaching, the importance of translation teaching, teaching materials, teaching methods, research into translation teaching, and teacher training. The paper concludes that the development of translation teaching depends on guidance from translation theory, and that effective translator training must incorporate the research and development of translation teaching theories. Therefore, teachers of translation must pay attention to translation studies as well as translation teaching theories.
\end{abstract}

\section{A BRIEF HISTORY OF TRANSLATION TEACHING}

Modern systems of foreign language instruction in mainland China began in 1862. From that point on, translation teaching was used as a means of teaching foreign languages and would not become an independent discipline until 1978. As early as 1944, Yan'an Foreign Languages School, set up to train translators and interpreters in politics, military affairs and foreign affairs, offered courses in translation and interpreting. It was perhaps the first official translation course in mainland China, although there is no record of definite teaching programs or textbooks. Between 1949 and 1978, some of the foreign language institutes or departments included courses in translation, but the timetables indicate that translation was used mainly as an exercise to practice a foreign language. No distinction was made between teaching translation and translation teaching. As a result, teaching plans had little in common and the study of and research into translation teaching was non-existent. Most teachers of translation let their students translate text and then commented on the students' work in class. This method was subjective and allowed teachers to follow their own 
inclination, but made it difficult to contrast results or compare notes on the teaching experience. The translation course was mainly targeted to undergraduates specializing in foreign languages, and there were no special departments or programs for training translators or interpreters. The number of qualified translators and interpreters graduated from foreign language institutes or departments was therefore very limited.

Since 1978, a number of foreign language institutes and departments have been established. According to incomplete 1989 statistics ( from Important Events of Foreign Languages Teaching in China 1949-1989, Foreign Languages Teaching and Research Press, 1993), there are nearly 400 universities or colleges with foreign-language departments, in addition to the foreign language institutes in Beijing, Shanghai, Guangzhou, Tianjin, Xi'an, Chongqing, Dalian and other cities, most of which offer courses in translation and interpreting to undergraduates. By 1990, more than 50 foreign-language universities or departments offered M.A. degrees in English language and literature, according to statistics of the State Commission of Education. Among those universities or departments, only a few were actually called "Translation Theory and Practice;" others included translation within the speciality of English language and literature. Thousands of undergraduate and graduate students graduated from these universities and departments between January 1982 and July 1996. Nearly all had learned translation, and most are now practicing translation or interpreting in various areas. M any postgraduate students go on to teach translation. They have also translated and published articles, works of literature and translation studies, as well works from other disciplines. They have also been interpreters in meetings, interviews and conferences. The results of China's translation teaching during this period is remarkable in terms of both quantity and quality: ever since 1978, real and official translation teaching has developed rapidly in mainland China.

\section{THE IMPORTANCE OF TRANSLATION TEACHING}

Not everybody recognizes the importance of translation teaching, but there is perhaps no other discipline of language and literature that so comprehensively reflects new research in linguistics, literature, aesthetics and other areas. Translation is an important component of foreign language training as well as a means of testing foreign language skills. The program combines translation, literature and linguistic theories with translation practice and courses aimed at improving comprehensive linguistic capability. Through translation teaching, students deepen their understanding of two languages and two cultures, learn both the foreign language and their mother tongue thoroughly, and enhance their knowledge of structure. The purpose of translation teaching is to give students not only practical bilingual ability, but also to encourage the attitudes and morality that will allow them to do the best possible translation work after graduation. From the students' point of view, translation is a very useful skill to graduate with. The level of translation reflects comprehensive abilities in a foreign language and the mother tongue (including listening, speaking, reading and writing) and even a comprehensive understanding. Graduates with strong translation or interpreting abilities can more easily find good jobs. In mainland China, translation is a compulsory course for undergraduates in foreign language departments. On the other hand, it is more difficult for students to write their 
graduation thesis (esp. at the graduate level) on translation than on linguistics or literature. There is less conference material than in linguistics and literature. Moreover, the thesis must be connected with translation theories that involve the theories of linguistics, literature and other branches of learning. In short then, the translation abilities of students will affect both their work and studies.

It becomes apparent that translation theory could be applied widely through translation teaching, and could then be studied in depth to set the course for continuous improvement in translation itself. A great number of high level translators and interpreters are needed to accomplish China's four modernizations. Translation teaching has been playing an important role in training these translators and interpreters, while also serving as the lifeline for the development of translation studies or translatology.

\section{THE CURRENT SITUATION OF TRANSLATION TEACHING}

I recently carried out a study of translation teaching that involved sending questionnaires to every English department or teacher of translation. The completed questionnaires tell us some basic facts about translation teaching in mainland China. First of all, almost all the English departments offer courses in translation. Some give E-C (English-Chinese) translation, some C-E, some both $\mathrm{E}-\mathrm{C}$ and $\mathrm{C}-\mathrm{E}$ translation. Not many departments teach interpreting, though it is a very important skill for students. Other departments combine $\mathrm{E}-\mathrm{C}$ and $\mathrm{C}-\mathrm{E}$ translation into one course. Generally speaking, $\mathrm{E}-\mathrm{C}$ translation is taught in the third year and $\mathrm{C}-\mathrm{E}$ in the fourth, two hours a week. Some departments combine E-C and C-E translation into a one-year third or fourth year course four hours a week. Every department arranges courses according to their own teachers, and not to make teaching programs identical. For instance, if a department was to teach C-E translation before advanced English writing, students would face many difficulties in English translation.

On Nov. 9-12, 1996, "the First National Symposium on Translation Teaching" was held in Nanjing, sponsored by the Translation Theory and Translation Teaching Committee of the Translators' Association of China. Over 100 teachers and translation graduates attended the symposium. They were interested in the following questions: What is a reasonable arrangement for translation courses? When should we give translation courses? How many hours should we spend on translation teaching every week and how many in total? Should we give C-E and E-C translation separately or combine them into one course? What is the basic content of and what are the key points in the translation course? How should we teach translation? The discussion proceeded intensely, but it was difficult to arrive at concensus as everyone stuck firmly to their own arguments.

Before this symposium, most articles related to translation teaching were about $\mathrm{E}-\mathrm{C}$ translation, few looked at C-E translation. Many teachers gradually noticed the importance of $\mathrm{C}-\mathrm{E}$ translation teaching and research, and began to discuss how to teach C-E translation effectively. One speaker advocated teaching E-C and C-E translation separately, believing that students use different linguistic, cultural, psychological and thinking methods when they are doing E-C and C-E translation. Teachers should therefore create environments conducive to learning different kinds of translation. Other speakers maintained that it was better to teach $\mathrm{E}-\mathrm{C}$ and $\mathrm{C}-\mathrm{E}$ translation 
together. In their opinion, students could thereby grasp the major point in both $\mathrm{E}-\mathrm{C}$ and $\mathrm{C}-\mathrm{E}$ translation - the differences between languages and cultural systems- and not waste time. Even though $\mathrm{E}-\mathrm{C}$ and $\mathrm{C}-\mathrm{E}$ translation employ different translation skills and techniques, there are similarities between teaching $\mathrm{E}-\mathrm{C}$ and $\mathrm{C}-\mathrm{E}$ translation, especially in dealing with the differences between languages and cultural systems. They recognized, however, that teaching $C-E$ translation was more difficult than teaching $\mathrm{E}-\mathrm{C}$ translation, because it is harder for students to express themselves in a foreign language than in their mother tongue. Teachers should encourage their students to be conscious of the fact that Chinese is a language of parataxis and English hypotaxis, and emphasize the great differences in the two cultural systems. The translator's task is to bridge the gap between both languages and cultural systems.

Most participants at the conference agreed, after some discussion, that E-C translation should be taught in the third year and $\mathrm{C}-\mathrm{E}$ and interpreting in the fourth as a separate course, two hours a week over two years. The basic objective of translation teaching is to help students establish correct translation criteria. Translation teaching should be guided by theory rather than simply to impart skills. At the undergraduate stage, translation teaching should pay special attention to translation practice and should deal, as a minimum, with: translation criteria, the relationship between language and culture, comparisons of English and Chinese, translation criticism, translation history, and a brief introduction to translation circles both at home and abroad.

\section{TEACHING MATERIALS}

Different departments have their own training objectives, and choose different textbooks accordingly. A Course in E-C Translation and A Course in C-E Translation were compiled and published in the early 1980 s. They have been used widely since then by most English departments. But as time goes on, more and more teachers are finding these textbooks out-of-date and unsuitable for present needs. The content of those two books is old and incomplete, with many examples drawn from newspapers or books published before 1980. They illustrate word and sentence translation, but not paragraph translation, nor the translation of an entire text. They also fail to touch on the comparison, appreciation and translation of various styles. Therefore, most teachers supplement the textbooks with lecture sheets or exercises they compile themselves. Some only use these two textbooks as reference books.

Some teachers have published their own textbooks, such as A Course on E-C and C-E Translation compiled by Ke Ping, A Course in Translative Art by Huang Long, A Practical Course in E-C Translation by Xu Qihua, A N ew Practical Textbook of Translation From Chinese into English by Chen Hongwei, A Course in Translation Between English and Chinese by Yang Lili, A N ew Book on E-C Translation by Li Zhengzhong and An Applied Theory of Translation by Fan Zhongying, to cite a few. These textbooks are all used by small pockets of teachers but, to date, none has been accepted and adopted as authoritative by most teachers. These textbooks each embody the translation criteria of their authors, who each have different answers to some basic questions, such as: How should translation theory be combined with translation practice in a textbook? How should translation theory guide the compilation of a textbook? What kinds of translation theories and skills should be taught to under- 
graduates? How should the content of the translation course be connected with that of other courses? Different teachers have applied different theories to their own textbooks. For example, Chen Hongwei is a proponent of translation theories guided by social-semiotics, Ke Ping of semiology, and Yang Lili of important viewpoints of modern translation theories, etc.

During the symposium, I suggested that we should arrive at a common understanding of the problems mentioned above through discussion, and then organize a team of experienced teachers to design a new translation teaching programme. The team could then compile a collection of textbooks under the guidance of the programme. This series now includes A Course on E-C Translation, A Course on C-E Translation, Appreciation and Analyzis of Translation, Translation Criticism, Comparative Study of English and Chinese and corresponding teachers' books and exercise books to form a complete set. This series of textbooks is suitable for different levels of students. Correspondingly, teachers of French, Japanese, German and Russian and other languages could compile or modify the textbooks they have available to form their own series.

\section{TEACHING METHODS}

We have focused primarily on the semantic transformation aspects and not the cultural exchange aspect of translation teaching, a point that was noted and discussed by many teachers. They realize that translators must pay special attention to cultural differences and that teachers should develop in their students a heightened cultural consciousness. The choice of teaching materials should be practical and instructive, and teaching methods should not be monotonous. Teachers must therefore be highly qualified, and have extensively studied the theories of translation, linguistics, literature, aesthetics and other related branches of learning. M oreover, they should be able to connect translation theory with practice and to apply the theory to translation skills. Teachers of translation should have a rich experience in the practice of translation and have published books or articles on translation studies. They should be familiar with English and American literature and with the cultural systems of both West and East. They should also be aware of the mistakes most often made by students, and be able to accurately analyze the causes of these mistakes from the theories of linguistics, culture, literature, rhetoric, style, aesthetics and so on.

Some teachers make their students do exercises such as translating a piece of writing before the lecture. In class, they will then explain the translation theories and skills relevant to the exercise. This is a useful and effective method, but is difficult for most teachers, as it requires that they be familiar with translation theories and skills themselves, and be able to combine these theories with translation practice. That is to say, they must be highly qualified translators first of all, and be able to explain translation theories and skills vividly and clearly so that their students can understand and assimilate these explanations. This is a challenge for all translation teachers. Other teachers will explain translation skills first, then give an assignment. After correcting the exercise-books, they will give a lecture again to highlight misunderstandings, mistaken translations and to point out the correct translation. Some teachers instruct their students to compare the correct translation with their own exercise in order to find their mistakes, analyze the reasons for these mistakes, and improve 
the translation themselves. Other teachers will discuss excellent passages from translations done by famous translators with their students. Most teachers emphasize the importance of translating whole paragraphs or texts. They provide articles of various styles in order to enrich practical translation abilities and stimulate the interest of students. In a word, all translation teachers spend a lot of time preparing lessons, correcting exercise-books, and doing practical translations themselves to enrich their own experience and knowledge. In a sense, translation teachers are more hard-working than the teachers of other subjects.

\section{RESEARCH INTO TRANSLATION TEACHING}

Improvements to the quality of translation teaching rely on teachers of translation. The Translation Theories and Translation Teaching Committee of the Translators Association of China was organized in 1995, and most members are teachers of translation. The Committee has been trying to find ways of enhancing translation teaching and research. For example, it is supporting my own investigation into translation teaching, and sponsors the translation teaching symposiums. Committee members are also preparing a report on persistent teaching problems that will be presented to related branches of the national government.

There have been regrettably few articles discussing translation teaching in periodicals and magazines of foreign languages and literature since 1980. Only the Chinese Translators' Journal has a column on translation teaching. From no. 1 volume of 1980 resuming publication to no. 6 volume of 1996, the Journal has published a total of 43 articles discussing translation teaching ('80, '81, '82, '83, '87 and '89 without this column). Adding these to articles published in other journals gives an annual average of three articles about translation teaching in the whole country. Compared with the large number of articles published in these journals about foreign languages and literature each year, along with those on other aspects of translation studies, this is negligible quantity.

Reference books may well be required for research purposes, but it is information that our teachers of translation need most urgently. Restricted by funds, most teachers and even departments and university libraries cannot afford to buy enough reference books to allow for serious research. Peking University, for example, has no more than 30 books on translation studies in the library of Beijing University, the best university in China. One can only imagine the situation at other universities. It is more difficult to find or purchase reference books published abroad. There is little chance for teachers of translation to get together and exchange related information and teaching experience, to discuss and solve important problems about translation teaching, such as the teaching programme, textbooks, content, methods, testing and the like. Few teachers of translation know much or anything about the strategies of other teachers or departments, such as what textbooks, teaching methods, examinations and reference books they use, and research into translation teaching is far inferior that on College English teaching. In College English teaching, there is a large variety of handbooks and test collections available. Teachers of College English often sponsor symposiums to get to know the teaching methods, test results and problems of other universities or departments, which helps teachers improve their own teaching and research enormously. 
Several months ago, I sent more than 100 questionnaires to departments of foreign languages and literature around China. Since English is the main foreign language taught in China, my investigation involves mainly English departments. These returned questionnaires reveal that teachers of translation often know little even about the teaching and research of other teachers in the same department, not to mention other departments or universities. More than 50 departments offer M.A. degrees in translation, and it is estimated that nearly 100 students are writing their graduation theses on translation studies each year. But it is very difficult for those graduates and their tutors to find out what subjects have been studied before. In order to change this situation, I put forth the suggestion that publishers support the publication of books on translation teaching for the benefit of all teachers and students of translation.

Among the published research articles on translation teaching, some deal with textbooks, teaching methods, a particular translation class or even how to teach the translation of a sentence or a paragraph; others treat the teaching of $\mathrm{E}-\mathrm{C}$ or $\mathrm{C}-\mathrm{E}$ translation, as well as interpreting; some look at the translation teaching in English majors and in College English; others compare translation teaching in mainland China with teaching in Hongkong or foreign countries. In a word, the subjects of research are wider, but some important questions are still going unnoticed, such as testing and evaluating translation, setting courses for both undergraduates and graduates, arranging homework, teachers' training, and so on.

It has been observed that not all people with good bilingual abilities can translate well. There may be a gap between the solid grasp of both languages and the artistic demands of translation; this is precisely the problem that translation teaching should resolve. What is needed to bridge this gap, and should therefore be taught in translation teaching? However, not everyone shares this viewpoint. Some believe that anyone with a solid bilingual foundation could accomplish perfect translations and see no gap whatsoever. Translation ability, in this view, is something innate which cannot be acquired through study, which then begs the question: Is there any need to teach translation? In my opinion, the answer is yes, and my survey would indicate that nearly all translation teachers agree. We all believe that it is necessary to teach translation. As long as there is a distinct teaching objective, a feasible teaching programme, a set of practical textbooks and an experienced teacher, students will emerge better equipped to work in translation after they graduate. Unless we can achieve concensus on the importance of translation teaching, the divergence of views will taint translation teaching as a profession. As teachers of translation, we should first have clear ideas about how to improve translation abilities. Then we must ask what problems need to be resolved in translation teaching. What should be taught and how it should be taught? H ow much time should be spent on translation teaching and which courses are useful? M any teachers agree that students of translation should take at least eight courses: translation theory, translation practice, translation criticism, comparative studies of English and Chinese language, semantics, stylistics, Chinese and English writing. Having agreed on this, we can then draw up reasonable teaching programmes for both undergraduate and graduate students, for students of foreign languages and non-foreign languages, and can begin to compile suitable translation textbooks. The result, we hope, would be more and better translators. 
In the process of teaching, exercises and tests are very important means of reinforcing the course material. However, little work has been done in these areas to date. This may have something to do with the disregard for translation courses. Several years ago, Professor Fan Shouyi and I published four articles on evaluating translations with the help of a fuzzy theory. Evaluating translations is one of the basic problems in translation tests. It is both an age-old and very new problem, which is similar to problems in more general literary criticism. Earlier methods began with analysis, discussion, comparison and description, then went on to comment on certain aspects of the translation by means of a series of qualitative expressions. Thus, it is known as the "qualitative evaluation method." The advantage of this method is that it is lively as it plays up function and literary appreciation. However, the method does not involve an all-encompassing evaluation and can be affected by subjective factors. Therefore, the result is not intuitive, exact and distinct. Based on the theory of the fuzzy set and principles of mathematical statistics, we put forward a fuzzy synthetic method of evaluation, which can reflect the quality of a translation objectively and in all its dimensions, with a more intuitive and distinct result. In the first place, the criterion of "faithfulness" is a fuzzy one, which reflects the fuzziness of translation itself. The consideration of individual factors is the central characteristic of the synthetic method of evaluation for the sake that where there is analysis, there is synthesis, and we set factors or factor set according to different styles. And the determination of the factor set and weighting of the coefficient set have the significance of direction or reference toward the evaluation of any style of translation except literature. Besides, statistical averages are an accurate and trustworthy guarantee in this method. M oreover, my attempts to put the method into practical usage have met with considerable success. I assign a fuzzy synthetic evaluation to several different styles. The whole course is authentic, detailed and specific. In order to make the evaluation more efficient, we have suggested developing a computer program to carry it out, something which appeals to non-professional people, who will be able to evaluate translations on their PCs.

Along with the evaluation of translations, the design of examination questions is another important component of exercises and testing. If exercise and examination questions do not reflect the course content and address difficulties in translation, the effectiveness of teaching cannot be accurately gauged. Most teachers only let their students translate words, sentences and paragraphs in exercises and examinations, which cannot reflect an all-round grasp of translation theory and practice. Some teachers recommend developing a test system which divides examinees into three levels, and gives each level appropriate questions. When designing questions, we should consider whether they are objective, ensure that at least some questions relate to translation theory, and pay special attention to the choice of subjective questions. In a word, exercises and examinations must include at least two aspects, theory and practice. Questions can take the form of fill-in-the-blanks, judgement, brief essay answers, criticism, discussion of theory, writing sample translations, choosing accurate translations, correcting mistakes and appreciating elegant translations. Further research on translation testing is needed in order to meet the needs of translation teachers.

Interpreting is one of the main components of translation teaching, and yet it is most often overlooked. Few university departments offer courses in interpreting, and the research on interpreting is sparse. Dr. Liu Heping, Dr. Cai Xiaohong, associate 
professor Wang Jun and other teachers of interpreting are presently discussing how translation theories can be integrated into the teaching of interpreting, how to best use teachers in the training of interpreters, and how to teach students to remember the numbers in their interpreting and so on.

In translation teaching, we have found that students' problems are largely attributable to the following factors: (1) Attitude toward their occupation: they do not recognize the importance of translation, so they do their homework casually and carelessly; (2) Weak bilingual foundation: both their comprehension and expression of Chinese and the foreign languages are not good enough. They often make grammatical and spelling mistakes, create Chinglish sentences when they do C-E translation, and sometimes use non-standard Chinese and incorrect punctuation marks. It is very hard for those with weak writing abilities (especially Chinese writing abilities) to catch up with others in a short time. (3) Rhetoric and style: students have no clear consciousness of style, and have had little chance to appreciate various styles before they begin to study translation. Correspondingly, they translate without considering the style of the original and often mix different styles together. (4) Cannot use reference books: students often ask their teachers the meaning or spelling of a new word rather than looking it up in a dictionary. They are used to asking teachers, even though they study background material by themselves. Some students use the Chinese translation appearing in pocket dictionaries without considering its definition, characteristics and usage. All these problems are due to our educational system and teaching method, and indicate that we must pay more attention to students' study and thinking methods.

\section{Teacher Training}

From the questionnaires that were completed in my study, we can see that $45 \%$ of all teachers of translation are under 45 years old, while $55 \%$ are over 45 . Most of the teachers over 45 will retire within several years. Even among teachers younger than 45 , most range from 38 to 43 years old, with only a few under 35 . The median age of translation teachers will be about 45 in just a few years. There will be fewer experienced teachers and translators to guide the younger teachers, and there will be fewer candidates to fill the current positions of middle-aged teachers, which is an ominous phenomenon. We are all anxious to train more and more qualified translation teachers as quickly as possible. Nevertheless, it is gratifying that almost all the young teachers have M.A. degrees, and that some even have doctoral degrees, which is in contrast to those over 50 who generally only achieved a B.A. But these younger teachers have generally not had as much translation and teaching experience and do not possess as solid a bilingual foundation as those over 50 . Moreover, facing economic hardship, many young teachers and graduates cannot resist the temptation to earn more money by working for large enterprises, despite their training as teachers of translation; or they seek to make money through their knowledge of a foreign language in their spare-time, rather than paying more attention to their teaching and research. We worry about this situation as we feel that teaching and teacher training demands more focused attention.

The art of translation is a comprehensive branch of learning which demands not only a solid bilingual foundation and an understanding of translation theory, but also 
a rich knowledge of other related branches of learning, such as linguistics, literature, literary criticism, semantics, semiotics, pragmatics, computer and fuzzy theory, etc., as well as plentiful translation practice. It takes a long time to train a translator, a scholar of translation studies and a teacher of translation. Therefore, it is impossible for an ordinary student to be successful in translation practice, research and teaching at a very young age. Young teachers should continually try to learn from their older colleagues and follow their example of meticulous scholarship, beautiful translation, broad experience and skilled teaching methods. In spite of holding M .A. or doctoral degrees and even being professors, we must be careful to renew our knowledge, sharpen our skills and continually perfect ourselves in all aspects of our lives. Only in this way can we really improve the quantity and quality of teachers of translation.

In the past 15 years, a large number of postgraduates in translation have become teachers of translation and are working hard in their departments. Translation is a difficult course, involving a tremendous amount of time spent correcting homework. Translation is very different from other branches of learning, especially the natural sciences as there is no unifed logical reasoning, no calculated formula and few standard answers in translation. Every student will produce a different version of a text, and experience unique difficulties and problems. Teachers have to spend much time preparing their lessons, studying translation theories, correcting exercise-books, and practicing translation themselves. The course is a real challenge both to teachers and their students.

I recently visited a number of translation schools or English departments with translation programmes in both Hongkong and Canada. I noticed some differences between their practices and those prevalent in mainland China. For example, almost all teachers of translation in Hongkong and Canada have a doctoral degree in translation, which means that they have been rigourously trained in translation studies and practice, and that they possess very strong bilingual abilities. In Canada, people whose mother tongue is English will chiefly do and teach French-English translation while those of French mother tongue will mainly do and teach English-French translation. $\mathrm{M}$ any Chinese teachers of translation have to do and to teach $\mathrm{E}-\mathrm{C}$ translation and $\mathrm{C}$-E translation at the same time because of a lack of English mother tongue teachers. Information about teaching programmes, individual courses, teachers and other materials about translation teaching are readily accessible in Hongkong and in Canada, while such information is difficult to find in mainland China. The translation schools in Hongkong and Canada offer a relatively complete education in translation, from training to undergraduate studies and on to M.A. and Ph.D. degrees. We can mainly offer translation courses for undergraduate students in foreign language departments and M.A. degrees in translation. There are some similarities between the countries however. Translation teachers work very hard both during and after class whether they are in Hongkong, Canada or mainland China. Articles and works of translation teaching are rare compared with those on other aspects of translation studies or even foreign language teaching. One common concern among translation teachers in both China and Canada is how to teach translation better to meet the increasing need for qualified translators, interpreters and translation teachers. We hope there will be more opportunities for Chinese and Canadian translation teachers to discuss such common problems and improve our translation teaching together. 
Generally speaking, the improvement of translation teaching depends on the guidance of translation studies. A translator's training depends on the research and development of translation teaching theory, which is an important part of translation studies. Therefore, teachers of translation must pay special attention to research on translation teaching theories and other translation theories. Problems such as the teaching programme, textbooks, course design, teaching methods, testing and teacher's training, need to be discussed. At the same time, we should encourage investigation into the current state of translation teaching, and the difficulties facing teachers and students, in order to identify and resolve these problems. In the past few years, translation studies have been divorced from translation practice, and research on translation teaching has fallen far behind the development of translation studies. But we believe that as long as all teachers of translation make a concerted effort to gain a good grasp of the basic steps, such as designing programmes, compiling textbooks and training teachers, we can certainly reverse this backward and passive trend in the near future and bring more and better translators and teachers of translation into being.

\section{REFERENCES}

Chinese Science \& Technology Translators Journal $(1988,1996)$ : no. 1, no. 6.

Chinese Translators Journal $(1980,1996)$ : no. 1, no. 6.

Journal of Foreign Languages (1989, 1996): no. 1, no. 6.

$\mathrm{Ke}, \mathrm{Fu}$ (1986): Brief History of Foreign Language Education in China, Shanghai, Shanghai Foreign Language Teaching Press.

- - (1989): On Teaching of Foreign Languages, Beijing, Beijing Foreign Language Teaching and Research Press.

Lei, Mu (1991): “Further Studies in Fuzzy Set Theory and Evaluation of Translations", Journal of Foreign Languages, no. 2, pp. 66-69.

- - (1992): "Further Discussion on Evaluation Sci-Tech Translation by Means of Fuzzy Mathematics", Chinese Science \& Technology Translators Journal, no. 4, pp. 39-42.

- - (1993): "Translation: the Studies and the Teaching", Chinese Translators Journal, no. 3, pp. 37-38.

- - (1995): "Comments on a Textbook of English-Chinese Translation", Chinese Translators Journal, no. 4, pp. 34-36.

- - (1995): "The Present Situation and Prospect of Studies on Translation Theory", China Journal of Foreign Languages, no. 4, pp. 31-36.

Long, Lao (1990): "Teaching Translation on a Basis of Theory Combined with Practice", Chinese Translators Journal, no. 6, pp. 36-38.

Runqing, Liu (1991): Language Testing and Its M ethod, Beijing, Beijing Foreign Language Teaching and Research Press.

Sh o uyi, Fan (1987): "Fuzzy Set and Translation Evaluation”, Chinese Translators Journal, no. 4, pp. 2-9.

Unpublished theses of the First National Symposium on Translation Teaching (Nanjing, Nov, 1996).

Zhongde, Liu (1994): "Considerations on the Teaching of Translation", Foreign Languages and Translation, no. 1, pp. 46-48. 